\title{
Effect of Multinutrient (N, P, K and Zn) Briquettes on Growth and Yield of Bt Cotton
}

\author{
B.H. Sunil $^{1 *}$, V.D. Patil ${ }^{2}$, M. Pushpalatha ${ }^{3}$ and V.M. Basavaprasad ${ }^{4}$ \\ ${ }^{1}$ Department of Soil Science and Agriculture Chemistry, Parbhani, India \\ ${ }^{2}$ Director of Instruction and Dean, Vasantrao Naik Marathwada Krishi Vidyapeeth, \\ Parbhani 431402, (M.S.), India \\ ${ }^{3}$ Department of Soil Science and Agriculture chemistry, Latur, India \\ ${ }^{4}$ Department of Soil Science and Agriculture chemistry, Badnapur, India \\ *Corresponding author
}

\begin{tabular}{|c|c|}
\hline & A B S T R A C T \\
\hline & \multirow{6}{*}{$\begin{array}{l}\text { An experiment was conducted at experimental farm of Department of Soil Science and } \\
\text { Agricultural Chemistry, Vasantrao Naik Marathwada Krishi Vidyapeeth, Parbhani during } \\
\text { kharif season, 2015-16. The effect of multinutrient briquettes was studied on growth, yield } \\
\text { and yield attributing character of Bt cotton. The experiment was laid out in a Randomized } \\
\text { Block Design with five treatments and four replications. The results of the investigation } \\
\text { revealed that height of Bt cotton plant at square formation, flowering, boll bursting and } \\
\text { harvest was continuously increasing in all the treatments. Maximum increase in height was } \\
\text { observed with the treatment receiving RDF through a fertigation in six splits followed by } \\
\text { multi nutrient NPK+ Zn briquette application. The maximum number of leaves was } \\
\text { observed with treatment RDF through a fertigation at square formation, flowering, boll } \\
\text { bursting and at last picking and next best treatment was application of NPK+ Zn through } \\
\text { briquette. The highest dry matter was recorded with RDF through a fertigation and NPK + } \\
\text { Zn briquette application at last picking and there was almost two fold increase in dry } \\
\text { matter from boll formation to last picking whereas the maximum number of bolls was } \\
\text { recorded in treatment RDF applied in six splits through soluble fertilizers by fertigation. } \\
\text { The application of } 80: 40: 40 \text { kg NPK kg ha }{ }^{-1} \text { through soluble fertilizers by fertigation in six } \\
\text { splits have produced more seed cotton yield which was at par with application of } \\
120: 60: 60 \mathrm{~N}, \mathrm{P}_{2} \mathrm{O}_{5} \text { and } \mathrm{K}_{2} \mathrm{O} \text { through briquettes. Besides, the addition of } 20 \mathrm{~kg} \mathrm{ZnSO}_{4} \text { in } \\
\text { NPK briquette proved its superiority over all treatment except fertigation. }\end{array}$} \\
\hline Keywords & \\
\hline & \\
\hline Article Info & \\
\hline $\begin{array}{l}\text { Accepted: } \\
\text { 07 September } 2017 \\
\text { Available Online: } \\
10 \text { November } 2017\end{array}$ & \\
\hline & \\
\hline
\end{tabular}

\section{Introduction}

Generally, farmers of the country nearly 15 million spread across 10 states are engaged in cotton production. It is grown on an area of 11.76 million hectares. This area of 11.76 million hectares constitutes around $38 \%$ of the world area under cotton cultivation. Several reports studies indicated that positive correlation between vegetative growth and the number of fruiting points produced by cotton is well known. $\mathrm{N}$ supplement therefore by split application becomes important as it is supplied ideally in a time when crop critically requires. Bt-cotton differs in its requirement either by total or part of it in the different stages of crop. Thus, nitrogen use efficiency can be increased and better used to attain the 
objective of higher production (Hallikari et al., 2010). Phosphorus is another important nutrient in cotton production. It is essential for vigorous root and shoot growth, promotes early boll development, hastens maturity, helps to overcome the effects of compaction, increases water use efficiency, and is necessary for energy storage and transfer in plants. The function of potassium in plant metabolism is different from that of other major nutrients. The later become part of the plant structure, whereas potassium largely remains as an ion in the cells and sap and helps to control the water intake and metabolism of the plant.

Patil et al., (2001) reported that the soil potassium reserves are depleted and crop yields found to be reduced. It is reported that high clay Vertisol once upon a time suppose to be having very high potassium content now responding for $\mathrm{K}$ application, which shows that the $\mathrm{K}$ content has been depleted. On the other hand, zinc is one of the plant micronutrients, involved in many enzymatic activities of plants. It functions generally as a metal activator of enzymes. Patil (2013) reported that zinc improves crop productivity almost as much as major nutrients do. It ranks the third most important limiting nutrient element, next to nitrogen and phosphorus in crop production. Besides increasing crop yield it increases the crude protein content, amino acids, energy value and total lipid in chickpea, soybean, black gram etc. with zinc application.

\section{Materials and Methods}

A field experiment was conducted at the Research Farm of Department of Soil Science and Agricultural Chemistry, College of Agriculture, Vasantrao Naik Marathwada Krishi Vidyapeeth, Parbhani during 201516. The location of experiment lies between $76^{\circ} 46^{\prime}$, east longitude and $19^{0} 16^{\prime}$ North latitude, having elevation of $423.46 \mathrm{~m}$ above the mean sea level. The mean temperature ranges from 20.9 (minimum) to $34.2^{\circ} \mathrm{C}$ (maximum) and relative humidity was 79.0 per cent throughout the wet seasons. The experimental soil belongs to taxonomic class Parbhani series of mixed montmorillonite hyperthermic Typic haplusterts. The soils were analyzed by following standard analytical procedure as outlined by Jackson (1973). The soil pH was 7.73; EC $046 \mathrm{dSm}^{-1}$, available nitrogen $140 \mathrm{~kg} \mathrm{ha}^{-1}$, available phosphorus $8.5 \mathrm{~kg} \mathrm{ha}$ and available potassium $699.26 \mathrm{~kg} \mathrm{ha}^{-1}$ and available zinc $0.53 \mathrm{mg} \mathrm{kg}^{-1}$. Bt cotton were grown on field at a spacing of $180 \times 30 \mathrm{~cm}^{2}$ with the gross plot size $7.2 \times 5.4 \mathrm{~cm}^{2}$. The experiment was laid out in randomized block design comprising of five treatments with four replications.

\section{Treatment details}

$\mathrm{T}_{1}$ : Absolute Control (No fertilizer application)

$\mathrm{T}_{2}$ : Soil application of 120:60:60 by $\mathrm{N}, \mathrm{P}_{2} \mathrm{O}_{5}$, $\mathrm{K}_{2} \mathrm{O} \mathrm{kg} \mathrm{ha}{ }^{-1}$ and Drip irrigation

$\mathrm{T}_{3}$ : RDF through fertigation (soluble fertilizer: 80:40:40 NPK kg ha ${ }^{-1}$ )

$\mathrm{T}_{4}:$ 120: 60: $60 \mathrm{~kg} \mathrm{NPK} \mathrm{ha}{ }^{-1}$ through briquettes with drip irrigation

$\mathrm{T}_{5}$ : Application of $\mathrm{NPK}+$ micronutrient briquettes (120:60: $60 \mathrm{NPK} \mathrm{kg} \mathrm{ha}{ }^{-1}+20 \mathrm{~kg} \mathrm{ha}^{-}$ ${ }^{1} \mathrm{ZnSO}_{4}$ ) these are applied in three split dose, $24 \mathrm{~N}, 36 \mathrm{P}_{2} \mathrm{O}_{5}, 36 \mathrm{~K}_{2} \mathrm{O}$ and $10 \mathrm{Zn} \mathrm{kg} \mathrm{ha}^{-1}$ at basal dose, $48 \mathrm{~N}, 24 \mathrm{P}_{2} \mathrm{O}_{5}, 24 \mathrm{~K}_{2} \mathrm{O}$ and $10 \mathrm{Zn}$ $\mathrm{kg} \mathrm{ha}^{-1}$ at square formation and $48 \mathrm{~N}$ at flower formation stage.

\section{Results and Discussion}

\section{Growth and yield attributes}

The plant height of $\mathrm{Bt}$ Cotton increased gradually within the treatments of various 
stages of crop i.e. 21.80 to $35.50 \mathrm{~cm}$ at 30 DAS, 58.10 to $70.0 \mathrm{~cm}$ at $60 \mathrm{DAS}, 65.28$ to $85.51 \mathrm{~cm}$ at 90 DAS and 84.05 to $101.50 \mathrm{~cm}$ at last picking stage. Application of soluble fertilizers through fertigation $\left(T_{3}\right)$ found better amongst all treatments in improving the height of cotton. Fertigation treatments recorded significantly higher plant height at all growing stages of cotton as compared to briquettes application. The next best treatment was application of fertilizer through NPKZn briquette. Similar findings were also reported by Wadtkar et al., (2001), Raskar et al., (2001), Patke et al., (2003), Veerputhirum et al., (2005), Reddy and Aruna (2010), Mussaddak et al., (2011) and Tekale (2000) (Table 1).

The number of leaves plant $^{-1}$ was recorded from square formation (30 DAS) stage to last picking i.e. harvest of cotton crop. In grand mean number of leaves were varied from 31.18 to 123.48 leaves per plant, this clearly indicates that number of leaves goes on increasing as crop proceeds towards maturity (Table 2). At square formation (30 DAS) stage the number of leaves plant ${ }^{-1}$ in treatment $\mathrm{T}_{1}$ was 29.05 which were increased to 34.86,flowering (60 DAS) stage and boll formation stage (90 DAS) number of leaves were increased from 52.55 to 75.50 and 79.35 to 97.10 and respectively due to application of recommended dose of soluble fertilizer through fertigation over soil application. Last picking stages it was observed that number of leaves increased from 84.25 to 143.65 and 130.50 due to fertigation and $\mathrm{NPK}+\mathrm{Zn}$ briquette application. The maximum number of leaves was recorded with $\mathrm{T}_{3}$ (RDF fertilizer through fertigation) followed by multinutrient briquette over conventional fertilizer application and control at all growth stages. These results resembled with the results that were reported by Mussaddak et al., (2001), Patke et al., (2003).

In depth scrutiny of data revealed that the dry matter (stalk) yield of Bt cotton at boll formation and at harvest varied from 84.45 to 120.09 and 297.40 to $409.48 \mathrm{~g} \mathrm{plant}^{-1}$, respectively due to application of soluble fertilizers through drip irrigation i.e. fertigation, which showed distinct superiority, followed by the briquette application proved superiority over conventional fertilizer application $\left(\mathrm{T}_{2}\right)$ and control $\left(\mathrm{T}_{1}\right)$. These findings are in accordance with Mussaddak (2001), Patke et al., (2003), Veerpurthiran et al., (2005) (Table 3).

$\mathrm{T}_{3}$ : RDF through fertigation (soluble fertilizer: 80:40:40 NPK kg ha ${ }^{-1}$ )

\begin{tabular}{|c|c|c|c|}
\hline Application & $\mathrm{N}\left(\mathrm{Kgha}^{-1}\right)$ & $\mathrm{P}\left(\mathrm{Kgha}^{-1}\right)$ & $\mathrm{K}\left(\mathrm{Kgha}^{-1}\right)$ \\
\hline Sowing & 12 & 8 & 8 \\
\hline 20 DAS & 16 & 8 & 8 \\
\hline 40 DAS & 16 & 8 & 8 \\
\hline 60 DAS & 12 & 8 & 8 \\
\hline 80 DAS & 12 & 8 & 8 \\
\hline 100 DAS & 12 & - & - \\
\hline & 80 & 40 & 40 \\
\hline
\end{tabular}

$\mathrm{T}_{4}:$ 120: 60: $60 \mathrm{~kg} \mathrm{NPK} \mathrm{ha} \mathrm{k}^{-1}$ through briquettes with drip irrigation

\begin{tabular}{|c|c|c|c|}
\hline Application & $\mathbf{N}\left(\mathrm{Kgha}^{-1}\right)$ & $\mathbf{P}\left(\mathrm{Kgha}^{-1}\right)$ & $\mathbf{K}\left(\mathrm{Kgha}^{-1}\right)$ \\
\hline Basal application & $\mathbf{2 4}$ & $\mathbf{3 6}$ & $\mathbf{3 6}$ \\
\hline Square formation & $\mathbf{4 8}$ & $\mathbf{2 4}$ & $\mathbf{2 4}$ \\
\hline Boll formation & $\mathbf{4 8}$ & $\mathbf{0 0}$ & $\mathbf{0 0}$ \\
\hline
\end{tabular}


Table.1 Effects of treatments on plant height $(\mathrm{cm})$ at various growth stages of Bt-cotton

\begin{tabular}{|c|c|c|c|c|c|}
\hline \multirow{2}{*}{ Treatments } & Treatment details & $\mathbf{3 0}$ DAS & $\mathbf{6 0}$ DAS & $\begin{array}{c}\text { Boll } \\
\text { formation }\end{array}$ & Last picking \\
\cline { 3 - 5 } & $\begin{array}{c}\text { Absolute Control(Drip } \\
\text { irrigation) }\end{array}$ & 21.80 & 58.10 & 65.28 & 84.05 \\
\hline $\mathbf{T}_{\mathbf{1}}$ & RDF(Soil) & 31.68 & 59.55 & 70.47 & 86.65 \\
\hline $\mathbf{T}_{\mathbf{2}}$ & $\begin{array}{c}\text { Soluble(fertigation) } \\
\text { Fertilizers }\end{array}$ & 35.50 & 70.0 & 85.51 & 101.50 \\
\hline $\mathbf{T}_{\mathbf{3}}$ & NPK Briquetes with Drip & 33.15 & 69.55 & 76.86 & 95.15 \\
\hline $\mathbf{T}_{\mathbf{4}}$ & $\begin{array}{c}\text { NPK + Zn Briquettes } \\
\text { with Drip }\end{array}$ & 35.45 & 70.80 & 83.33 & 99.25 \\
\hline $\mathbf{T}_{\mathbf{5}}$ & Grand mean & $\mathbf{3 1 . 5 1}$ & $\mathbf{6 5 . 6 0}$ & $\mathbf{7 6 . 2 9}$ & $\mathbf{9 3 . 3 2}$ \\
\hline \multicolumn{2}{|r|}{} & $\mathbf{0 . 3 3 4}$ & $\mathbf{0 . 2 7 8}$ & $\mathbf{0 . 2 2 3}$ & $\mathbf{0 . 5 6 3}$ \\
\hline \multicolumn{2}{|c|}{ S.Em ( \pm CD at 5\% } & $\mathbf{1 . 0 4 2}$ & $\mathbf{0 . 8 6 5}$ & $\mathbf{0 . 6 9 6}$ & $\mathbf{1 . 7 5 4}$ \\
\hline
\end{tabular}

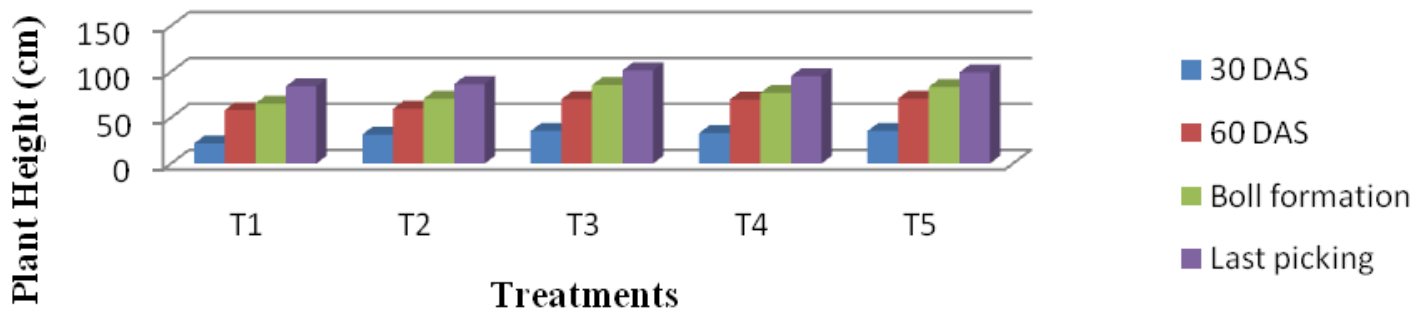

Table.2 Effects of treatments on number of leaves at various growth stages of Bt-cotton

\begin{tabular}{|c|c|c|c|c|c|}
\hline \multirow{2}{*}{ Treatments } & \multirow{2}{*}{ Treatment details } & \multicolumn{4}{|c|}{ Number of leaves } \\
\cline { 3 - 6 } & & 30 DAS & 60 DAS & Boll formation & Last picking \\
\hline $\mathbf{T}_{\mathbf{1}}$ & Absolute Control & 29.05 & 52.55 & 79.35 & 84.25 \\
\hline $\mathbf{T}_{\mathbf{2}}$ & RDF & 29.10 & 62.09 & 84.25 & 122.16 \\
\hline $\mathbf{T}_{\mathbf{3}}$ & Soluble Fertilizers & 34.86 & 75.50 & 97.10 & 143.65 \\
\hline $\mathbf{T}_{\mathbf{4}}$ & NPK Briquettes & 31.38 & 67.63 & 88.60 & 126.78 \\
\hline $\mathbf{T}_{\mathbf{5}}$ & NPK + Zn Briquettes & 31.55 & 62.24 & 93.65 & 130.60 \\
\hline \multicolumn{2}{|c|}{ Grand mean } & $\mathbf{3 1 . 1 5}$ & $\mathbf{6 4 . 0 0}$ & $\mathbf{8 8 . 5 9}$ & $\mathbf{1 2 1 . 4 8}$ \\
\hline \multicolumn{2}{|c|}{ SEm ( \pm CD at 5\% } & $\mathbf{0 . 3 4 0}$ & $\mathbf{0 . 5 3 8}$ & $\mathbf{0 . 4 6 3}$ & $\mathbf{0 . 7 2 4}$ \\
\hline \multicolumn{2}{|c|}{} & $\mathbf{1 . 0 6 0}$ & $\mathbf{1 . 6 7 8}$ & $\mathbf{1 . 4 4 4}$ & $\mathbf{2 . 2 5 5}$ \\
\hline
\end{tabular}

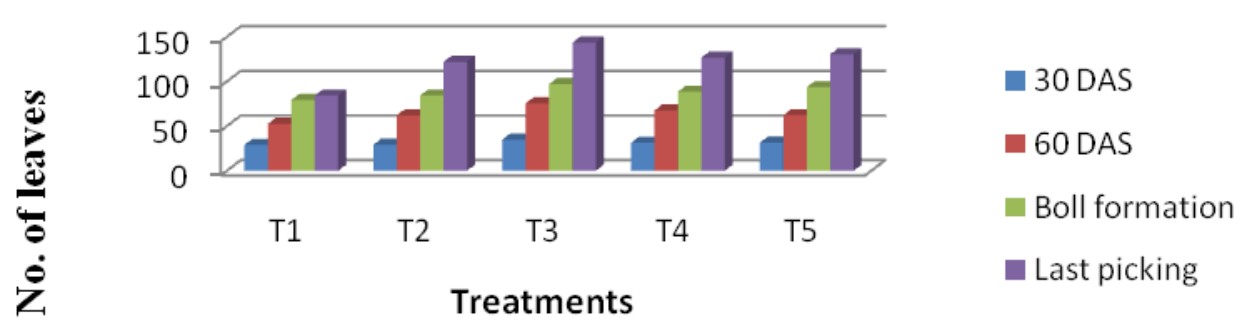


Table.3 Effects of treatments on dry matter (gm plant $\left.{ }^{-1}\right)$ at various growth stages of Bt-cotton

\begin{tabular}{|c|c|c|c|c|}
\hline \multirow{2}{*}{ Treatments } & \multirow{2}{*}{ Treatment details } & \multicolumn{3}{|c|}{ Dry matter (gm plant $\left.{ }^{-1}\right)$} \\
\hline & & 60 DAS & Boll formation & Last picking \\
\hline $\mathbf{T}_{1}$ & Absolute Control & 35.35 & 84.45 & 297.40 \\
\hline $\mathbf{T}_{2}$ & RDF & 35.99 & 105.34 & 347.94 \\
\hline $\mathbf{T}_{\mathbf{3}}$ & Soluble Fertilizers & 38.43 & 120.09 & 409.48 \\
\hline $\mathbf{T}_{4}$ & NPK Briquettes & 36.22 & 113.13 & 356.26 \\
\hline $\mathbf{T}_{5}$ & NPK + Zn Briquettes & 37.41 & 119.61 & 359.41 \\
\hline \multicolumn{2}{|c|}{ Grand mean } & 36.68 & 108.52 & 354.13 \\
\hline \multicolumn{2}{|c|}{$\operatorname{SEm}( \pm)$} & 0.280 & 0.506 & 1.777 \\
\hline \multicolumn{2}{|c|}{ CD at $5 \%$} & 0.871 & 1.576 & 5.537 \\
\hline
\end{tabular}

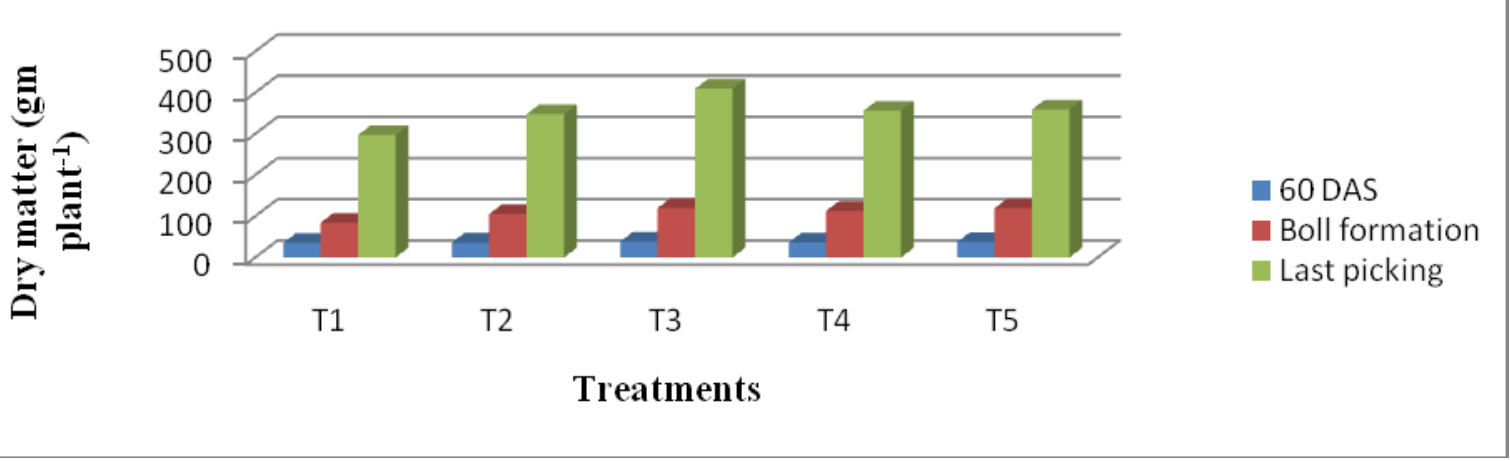

Table.4 Effects of treatments on total no of boll/plant (No.) and boll weight (gm) at various growth stages of Bt-cotton

\begin{tabular}{|c|c|c|c|}
\hline Treatments & Treatment details & Total no of boll/plant (No.) & Boll weight(gm) \\
\hline $\mathbf{T}_{\mathbf{1}}$ & Absolute Control & 44.88 & 4.37 \\
\hline $\mathbf{T}_{\mathbf{2}}$ & RDF & 47.87 & 5.19 \\
\hline $\mathbf{T}_{\mathbf{3}}$ & Soluble Fertilizers & 51.83 & 5.75 \\
\hline $\mathbf{T}_{\mathbf{4}}$ & NPK Briquettes & 51.63 & 5.25 \\
\hline $\mathbf{T}_{\mathbf{5}}$ & NPK + Zn Briquettes & 51.77 & 5.55 \\
\hline \multicolumn{2}{|c|}{ Grand mean } & 49.59 & 5.22 \\
\hline \multicolumn{2}{|c|}{ CDE $\mathbf{( \pm )}$} & 0.432 & 0.15 \\
\hline \multicolumn{2}{|c|}{} & 1.345 & 0.469 \\
\hline
\end{tabular}

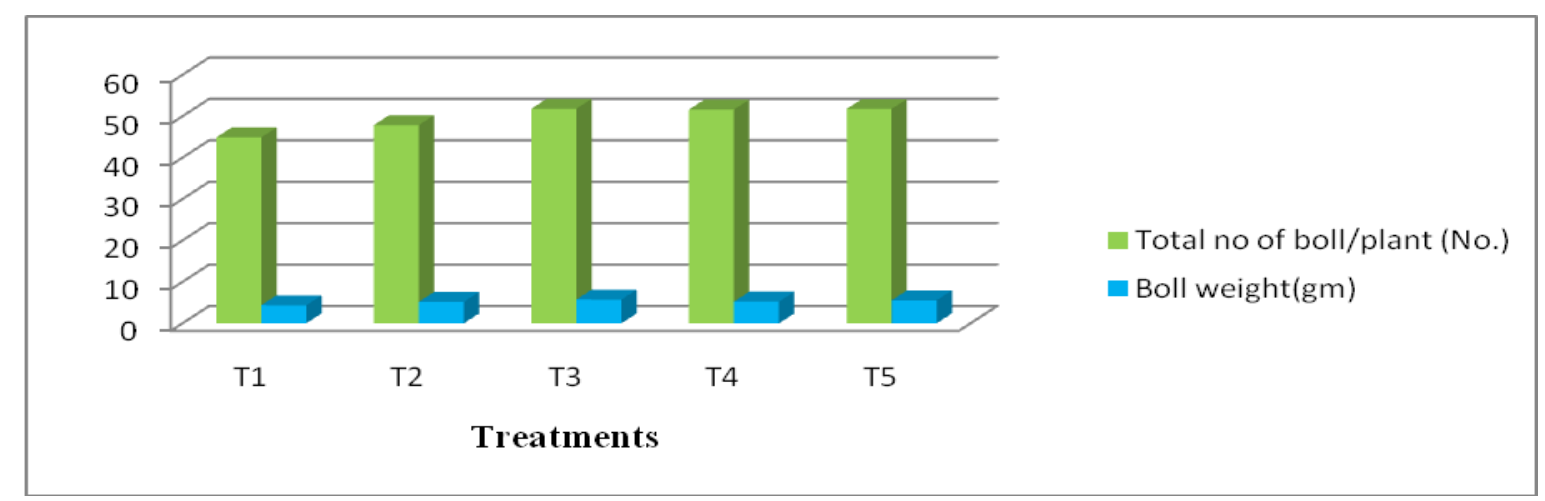


Table.5 Effects of treatments on seed cotton yield $\left(\mathrm{q} \mathrm{ha}^{-1}\right)$ and Stalk yield $\left(\mathrm{q} \mathrm{ha}^{-1}\right)$ at various growth stages of Bt-cotton

\begin{tabular}{|c|c|c|c|}
\hline Treatments & Treatment details & $\begin{array}{l}\text { Seed cotton } \\
\text { Yield } q / \mathrm{ha}\end{array}$ & $\begin{array}{c}\text { Stalk Yield } \\
\text { q/ha }\end{array}$ \\
\hline $\mathbf{T}_{\mathbf{1}}$ & Absolute Control & 10.74 & 54.35 \\
\hline $\mathbf{T}_{2}$ & RDF & 12.15 & 63.50 \\
\hline $\mathbf{T}_{\mathbf{3}}$ & Soluble Fertilizers & 15.59 & 74.84 \\
\hline $\mathbf{T}_{4}$ & NPK Briquettes & 11.670 & 65.14 \\
\hline $\mathbf{T}_{5}$ & $\mathrm{NPK}+\mathrm{Zn}$ Briquettes & 14.11 & 65.64 \\
\hline \multicolumn{2}{|c|}{ Grand mean } & 12.85 & 64.69 \\
\hline \multicolumn{2}{|c|}{$\operatorname{SEm}( \pm)$} & 0.173 & 0.51 \\
\hline \multicolumn{2}{|c|}{ CD at $5 \%$} & 0.539 & 1.54 \\
\hline
\end{tabular}

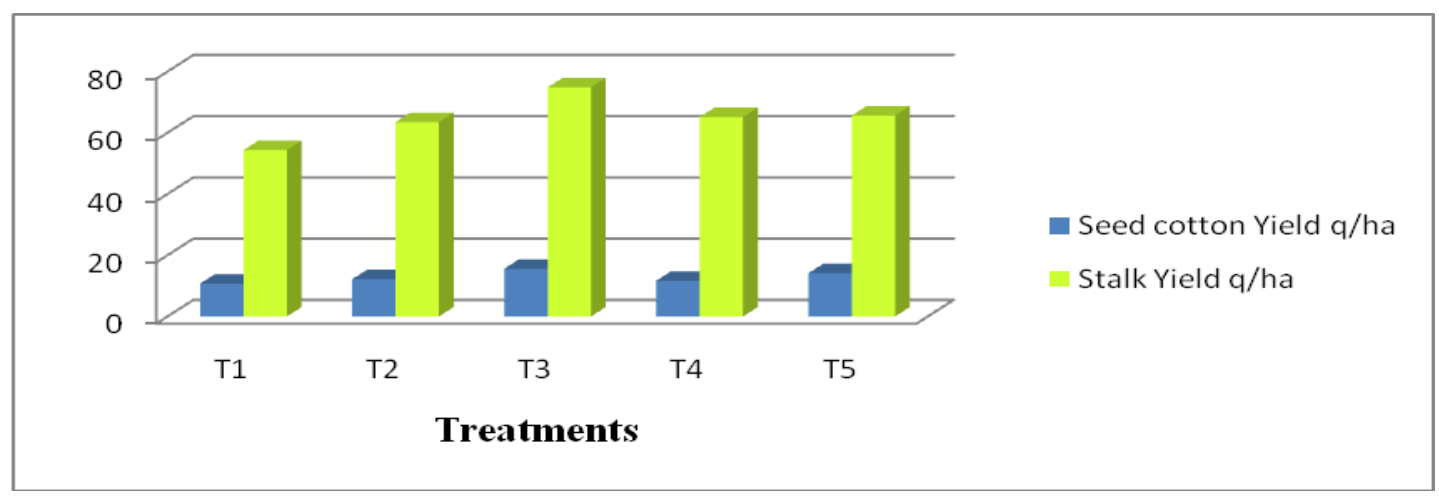

Yield attributes revealed that number of bolls per plant increased from 44.88 to 51.83 , respectively. The maximum number of bolls per plant and boll weight was observed with treatment $\mathrm{T}_{3}$ (RDF through fertigation with water soluble fertilizer). However the number of bolls produced under treatment NPK briquette and NPK $+\mathrm{Zn}$ briquette were almost same. Treatment $\mathrm{T}_{3}, \mathrm{~T}_{4}$ and $\mathrm{T}_{5}$ showed significant increase in number of bolls per plant over control and RDF (conventional fertilizer). These findings are achieved by application of nutrients by fertigation in conformation with earlier reported by Veerapurthiran and Chinnusamy (2005), Bharambe et al., (1997) (Table 4).

The yield of cotton regarding effect of multinutrient briquettes, conventional fertilizer application and fertigation are presented in Table 5, The application of soluble fertilizers have significantly produces maximum cotton yield $\left(15.59 \mathrm{q} \mathrm{ha}^{-1}\right)$ compared to other treatments. The Dry matter (Stalk) yield recorded under same set of treatment followed the trend of seed cotton yield. From the above results, it can be inferred that due to application of soluble fertilizer through fertigation improved the seed cotton and stalk yield these are reported by Bharambe et al., (1997), Tumbare et al., (1999), Thind et al., (2008).

From the result and discussion of this study, it can be concluded that the growth and yield of Bt cotton showed significantly superior with the application of RDF through a fertigation (soluble fertilizer) @ 80:40:40 NPK kg ha ${ }^{-1}$ followed by multinutrient NPK $+\mathrm{Zn}$ briquettes application@120:60:60 NPK +20 $\mathrm{ZnSO}_{4} \mathrm{Kg} \mathrm{ha}^{-1}$. 


\section{References}

Bharambe, P. R., Narwade S.K., Oza, S. R, Vaishnava, V. G., Shelke D. K. and Jadhav G. S. (1997). Nitrogen management in cotton through drip irrigation. J. Indian Soc. Soil Sci. 45(4): 705-709.

Hallikeri, S. S. Halemani, H. L., Mahajanashetty and Patil, B. C. (2010). Effect of fertigation on cotton productivity. Annual Report submitted in Annual workshop, CICR, Nagpur, April, 24, 2010: P-37.

Jackson, M. L. (1973). Soil chemical analysis. Prentice Hall of India Pvt. Ltd., New Delhi. pp. 134-182.

Mussaddak Janat., Somi G. (2001). Performance of cotton crop grown under surface irrigation and drip fertigation. Seed cotton yield, dry matter production and lint properties. Comm. Soil. Sci. and Pl. Analysis. 32(19/20):3045-3061.

Patil, V. C., H. L. Halemani, B. T. Nadagouda, R. Naganagouda, B. S. Yenagi and Rudragouda. (2004). Studies on irrigation requirement of hybrid cotton (Gossypium hirsutum L.) under drip irrigation. International Symposium on "Strategies for Sustainable Cotton Production - A Global Vision", Vol. 2. Crop Production. held on $23^{\text {rd }}$ to $25^{\text {th }}$ November, UAS, Dharwad, Karnataka.

Patil, V. D, Pholane, L.P. and Adsul, P.B. (2001). Plant nutrient mining in different agroclimatic zones of Maharashtra. Fertilizer News July 2001: 46(7)/43-48 and 51-54.

Patke, N. K. (2003). Nitrogen management of pre-monsoon hybrid cotton through fertigation. M.Sc. Thesis (Unpub.), Dr. PDKV. Akola.

Raskar, B. S., P. G. Bhoi and D. D. Pawar. (2001). Effect of planting technique and water soluble fertilizers on pre-monsoon cotton under drip irrigation J. Indian Soc. Cotton Improv. 26(3): 138-143.

Reddy, S., B. and E. Aruna. (2010). Effects of doses and split application of nutrients through fertigation in $\mathrm{Bt}$ cotton (Gossypium hirsutum L.) J. Cotton Res. Dev. 24(1): 59-63.

Tekale, D. D., R. K. Patil, M. R. More, R. G. Nadre and V. G. Vaishnav. (2000). Effect of different levels of nitrogen application through drip irrigation on the yield of cotton (cv. NHH-44). J. Soils Crops. 10(1): 66-68.

Thind, H. S., M. S. Aujla, G. S. Buttar. (2008). Response of cotton to various levels of nitrogen and water applied to normal and paired sown cotton under drip irrigation in relation to check-basin. Agricultural Water Management. 95: 25-34.

Tumbare, A. D., B. N. Shinde and S. U. Bhoite. (1999). Effects of liquid fertilizer through drip irrigation on growth and yield of okra (Hibiscus esculentus). Indian J. Agron. 44: 176-178.

Veeraputhiran R., Kandasamy O. S., Singh S. D. S., Chinnusamy C. (2005) Influence of drip irrigation and nitrogen fertigation on growth and yield of hybrid cotton. $J$. Ecobiology. 17(4):329-335.

Wadatkar, S. B., Thakare, S. H., Bhamodkar, M. A. and Deshmukh, H. D. (2001). Feasibility of liquid fertilizer through drip irrigation to cotton. PKV Res. J. 25(1): 54-55.

\section{How to cite this article:}

Sunil, B.H., V.D. Patil, M. Pushpalatha and Basavaprasad, V.M. 2017. Effect of Multinutrient (N, $\mathrm{P}, \mathrm{K}$ and $\mathrm{Zn}$ ) Briquettes on Growth and Yield of Bt Cotton. Int.J.Curr.Microbiol.App.Sci. 6(11): 717-723. doi: https://doi.org/10.20546/ijcmas.2017.611.084 